\title{
Petrography and Geochemistry of Precambrian Basement Straddling the Cameroon-Chad Border: The Touboro Baïbokoum Area
}

\author{
Naïmou Seguem 1,2, Ganwa Alembert Alexandre ${ }^{2,3 *}$, Urs Klötzli ${ }^{3}$, \\ Amadou Diguim Kepnamou², Ekodeck Georges Emmanuel ${ }^{4}$ \\ ${ }^{1}$ Department of Geology, Faculty of Sciences and Techniques, University Adam Barka of Abeche, Abeche, Chad \\ ${ }^{2}$ Department of Earth Sciences, Faculty of Sciences, University of Ngaoundere, Ngaoundere, Cameroon \\ ${ }^{3}$ Labor für Geochronologie, Department für Lithosphärenforschung, Universität Wien, Wien, Austria \\ ${ }^{4}$ Department of Earth Sciences, Faculty of Sciences, University of Yaounde I, Yaounde, Cameroon \\ Email: "ganwa1@yahoo.fr, ${ }^{*}$ alembert.alexandre.ganwa@univie.ac.at
}

Received 11 February 2014; revised 12 March 2014; accepted 9 April 2014

Copyright (C) 2014 by authors and Scientific Research Publishing Inc.

This work is licensed under the Creative Commons Attribution International License (CC BY). http://creativecommons.org/licenses/by/4.0/

c) (7) Open Access

\begin{abstract}
The border of Cameroon and Chad is characterized by a Precambrian basement straddling the Touboro-Baïbokoum area; this basement is made up of gneiss, amphibolite and granitoids (granite, syenite, granodiorite). The studied rocks display high-K calk-alcalcaline to shoshonitic characteristic. Granitoids are metaluminous. Rocks under study derived from partial melts from metabasaltic to metatonalitic sources, and partial melts from metagreywackes. They shear the same origin as many granitoids describe westward in the Meiganga area and west Cameroon. This shows that the basement straddling the Touboro-Baïbokoum area belongs to the Adamawa-Yadé Domain of the Central African Fold Belt.
\end{abstract}

\section{Keywords}

Precambrian Basement, Touboro-Baïbokoum, Cameroon, Chad, Adamawa-Yade Domain, Central African Fold Beld

\section{Introduction}

The main geological feature of central Africa is the predominance of Precambrian basement units. Much of this

"Corresponding author.

How to cite this paper: Seguem, N., Alexandre, G.A., Klötzli, U., Kepnamou, A.D. and Emmanuel, E.G. (2014) Petrography and Geochemistry of Precambrian Basement Straddling the Cameroon-Chad Border: The Touboro Baïbokoum Area. International Journal of Geosciences, 5, 418-431. http://dx.doi.org/10.4236/ijg.2014.54040 
basement is constituted by the formations of the Panafrican Central Africa Fold Belt (CAFB) [1], also known as the North Equatorial Panafrican Fold Belt [2]. The Congo craton to the south is considered as the foreland of the belt [3]. Previous works [4]-[7] involved in regional correlation divided the Central Africa Fold Belt into three main domains: 1) the Yaoundé Domain (YD), a huge nappe unit thrusted southward onto the Congo craton; 2) the Adamawa-Yadé Domain (AYD), a Paleoproterozoic basement which was dismembered during the Panafrican orogeny and which extends east of the Tcholliré-Banyo shear zone; 3) the Western Cameroon Domain (WCD) located west of the Tcholliré-Banyo shear zone (TBSZ) and which extends along the western border of Cameroon (Figure 1). Only limited cross-border geological research has been undertaken between Cameroon and Chad; one can cited: petrographic and structural studies on the rhyolitic domes of Dandi-Hadjer El Hamis, to the south of Lake Chad, considered as the extension of the Cameroon volcanic Line [8]; zircon dating of the Mayo Kebbi area regarded as the equivalent of the Poli series in Cameroon [9]. Geological correlation between the two countries is often based on the geographical continuation than on any geological consideration. This paper presents the results of a petrography and geochemistry study of the Precambrian basement straddling the Chad and Cameroon border in the Toboro-Baibokoum area. It appears that this area belongs to the AYD of the Central African Fold Bet (Figure 1).

\section{Geological Setting}

The Touboro-Baïbokoum area (Figure 2) belongs to the Adamawa Yadé Domain of the Central Africa Fold Belt, which stretches ENE through Cameroon, southern Chad and also possibly the Northern Central Africa Republic. This central part of the CAFB, better studied in Cameroon, is characterized by the wide spread occurrences of granitoids hosted in ortho- and para-gneiss, and associated with regional transcurrent shear zone [10]. Granitoids of the AYD have been classified into syntectonic, late tectonic and post tectonic, with respect to their solid state of deformation [6] [11]-[13]. Granitoids are made up of granodiorites and granites of various compositions. In the Baïbokoum area, the metamorphic rocks form enclaves in the granitoids. The rocks are made up of schist, quartzite, and gneiss with intercalation of amphibolite [14]. Granitoids can be divided into postectonic granitoids, which cross cut the old granitoids and considered as the latest magmatic manifestation of the Panafrican orogeny [1]. Old granitoids are made up of granites, granodiorite and monzonite, which show syntectonic

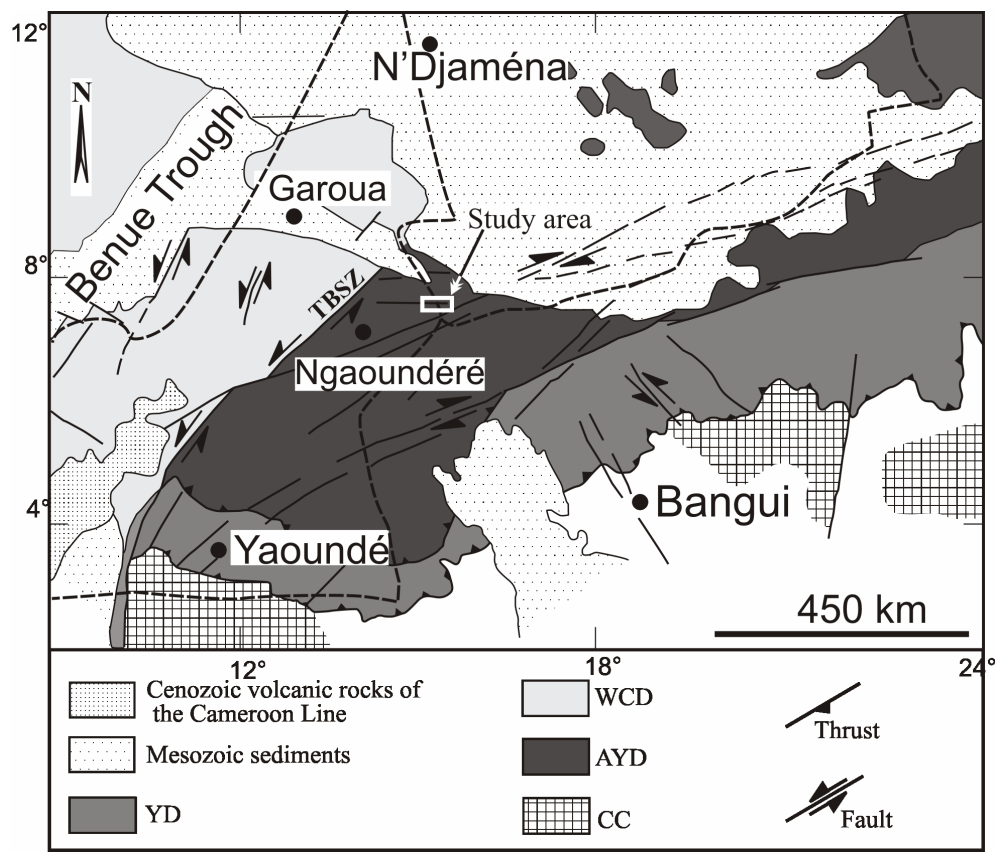

Figure 1. Geological sketch map of the Central Africa Fold Belt (CAFB) showing the study area. Redrawn after [4]-[7]. TBSZ: Tcholliré-Banyo shear zone; YD: Yaoundé Domain; WCD: West Cameroun Domain; AYD: Adamaoua-Yadé Domain; CC: Congo Craton. 
stretching parallel to the schistosity of the metamorphic rocks. These old granitic rocks were considered as old Precambrian crust reactivated during the Pan-African orogeny [15] until Toteu et al. [16] demonstrate in the Poli area (Cameroon): their syn-tectonic emplacement at $630 \mathrm{Ma}$, their relatively low ${ }^{87} \mathrm{Sr} /{ }^{86} \mathrm{Sr}$ initial ratios and conclude that they represent material newly added to the crust during the Pan-African orogeny.

\section{Analytical Methods}

Petrography of 30 thin sections covering all rock types has been made. Chemical analyses were carried out on 14 samples. Major and trace elements were analyzed by X-ray fluorescence at the University of Tübingen for 9 samples and at the MIPROMALO (Mission of Promote Local Materials), Yaoundé for 5 samples. Analytical uncertainties are estimated at $\pm 1 \%$ for major elements and $5 \%$ - $10 \%$ for most trace elements.

\section{Petrography of the Studied Samples}

Samples under study are made up of plutonic and metamorphic rocks. Pyroxene-amphibole-biotite bearing granite (PABG) forms a NE-SW band (Figure 2) in the middle of the investigated area, and crops out as flagstone (Figure 3(a)) or boulders. The tardi-tectonic nature of the PABG is highlighted by a weak schistosity marked by the alignment of biotite and amphibole. The rock is porphyritic in texture, with megacrysts of K-feldspar (2 - 3 $\mathrm{cm}$ ) in a groundmass of quartz, plagioclase, K-feldspar, amphibole, biotite and clinopyroxene. Accessories minerals such as zircon, titanite and opaque minerals are present. Clinopyroxene appears as remnant or rimed by the amphibole (Figure 3(b)), which is a green hornblende associated to the biotite; biotite also appears along the cleavage plane of the hornblende (Figure 3(c)).

The amphibole-biotite granite (ABG) occupies the NW of the studied area (Figure 2) and forms hills cover by boulders of various sizes (Figure 4(a)). Enclaves of amphibolite of various sizes are present in the ABG at the level of the Vina River at Touboro (Figure 4(b)). It has a granular magmatic texture. Amphibole is regularly associated to biotite and both highlight a faint schistosity in the rock. The K-feldspar exhibits distinct carlsbad twins and the contact with plagioclase crystals is occasionally characterized by a myrmekitic texture. Plagioclase sometime portrays optical zoning. Quartz occurs as subhedral crystals with undulose extinction. Accessories minerals are titanite and opaque minerals.

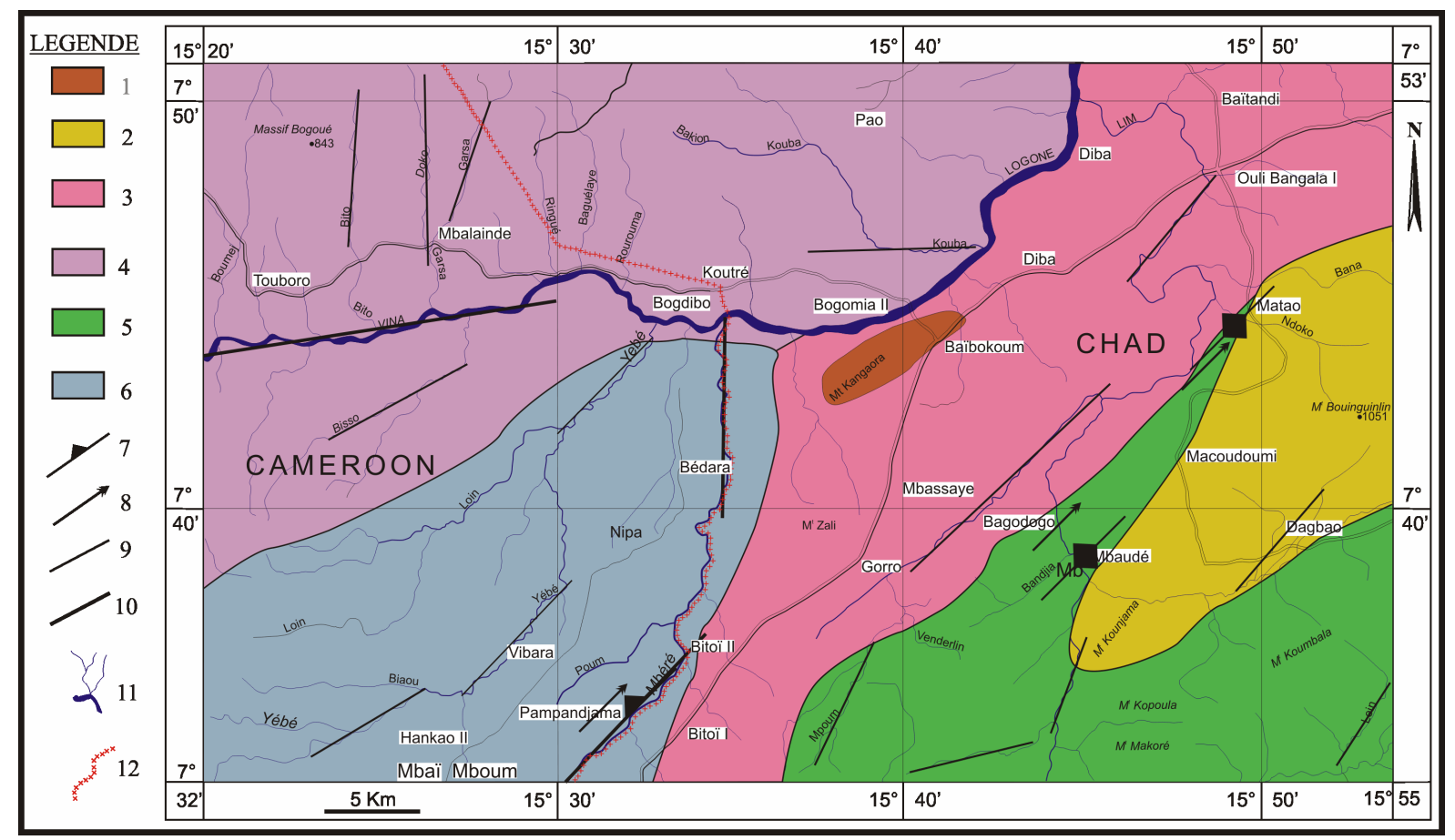

Figure 2. Geological map of the Touboro-Baïbokoum area 1: syenite; 2: G; 3: PABG; 4: ABG; 5: ABGn; 6: PGGn; 7: S2 Schistosity; 8: L2 lineation; 9: fracture; 10: fault; 11: rivers; 12: international border. Abbreviations as in the text. 


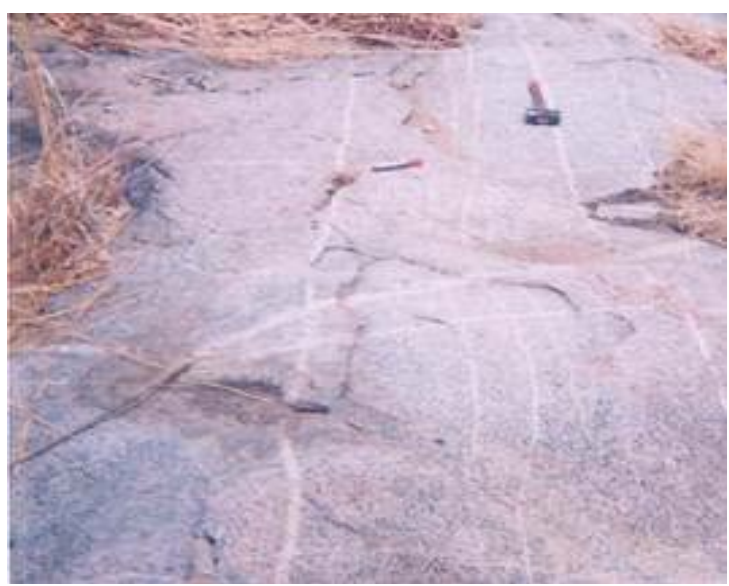

(a)

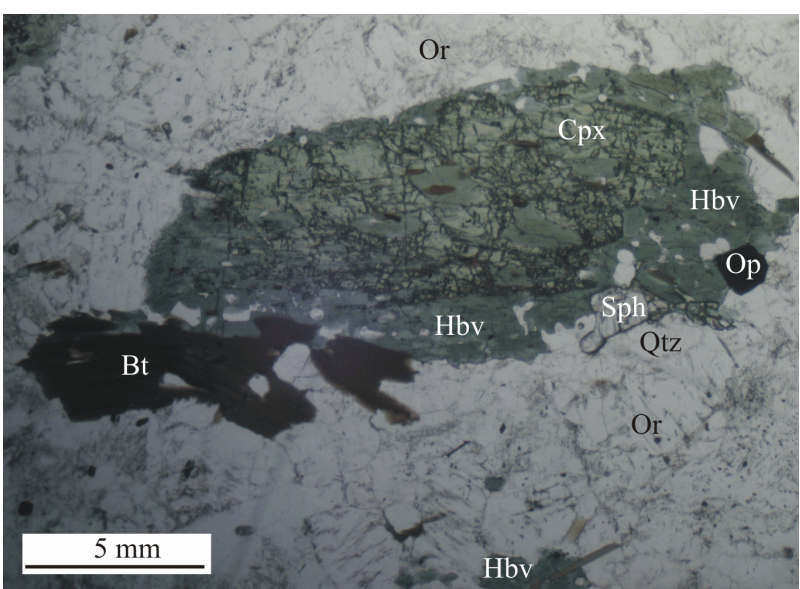

(b)

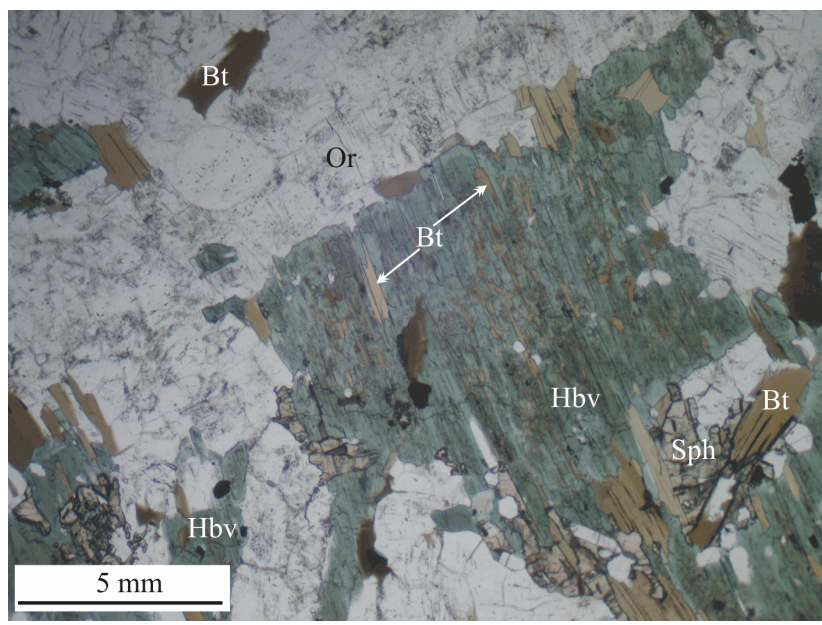

(c)

Figure 3. (a) Out crop of pyroxene-amphibole-biotite granite as flagstone at Gorro (N7 $37^{\prime} 10^{\prime \prime}$, E15 $\left.36^{\circ} 30^{\prime \prime}\right)$ note the presence of pegmatite dykes; (b) Clinopyroxene rimed by green hornblende in the pyroxene-amphibole-biotite granite; (c) Association of amphibole, biotite, Kfeldspar; note the biotite along the clivage of amphibole. Or: Kfeldspar, Bt: biotite, Hbv: green hornblende, Sph: sphene.

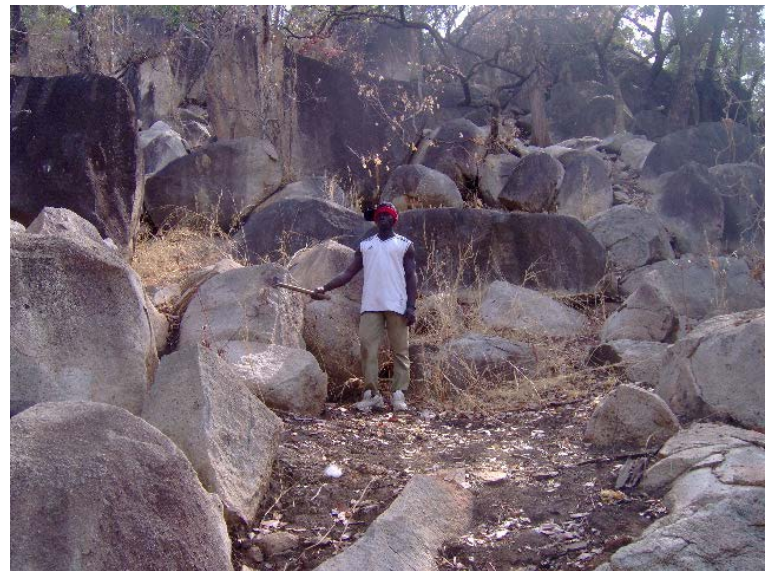

(a)

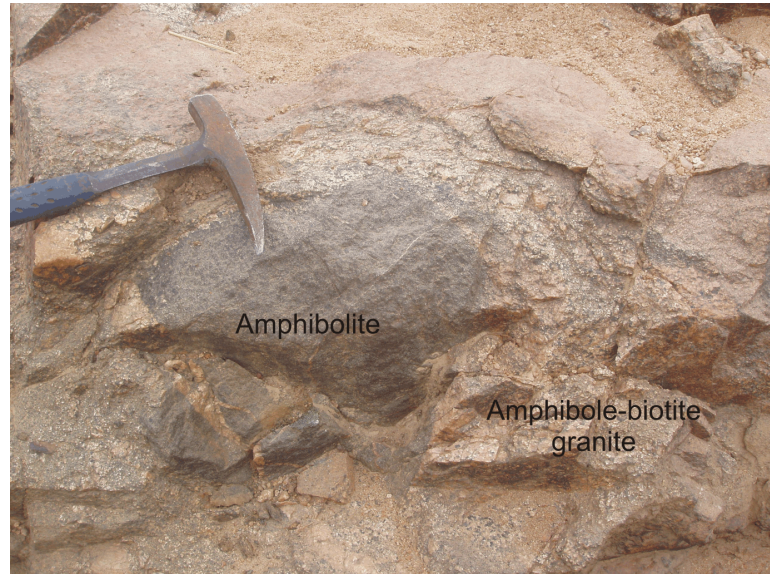

(b)

Figure 4. (a) Out crops of amphibole biotite granite forming boulders of various sizes at Touboro (N749'26"; E15¹9'52"); (b) Enclave of amphibolite in the amphibolite-biotite granite in the river Vina at Touboro (N7 $47^{\prime} 14^{\prime \prime}$; E15 $\left.00^{\circ} 38^{\prime \prime}\right)$. 
Granodioritic rocks (G) crop out to the East of the studied area; it form NE-SW stretching hills cover by blocs of various sizes. At the out crops scale, granodiorite is characterized by phenocrystal of K-feldspar with inclusion of amphibole (Figure 5(a)). In thin section, the studied sample portrays mark of deformation with protomylonitic texture (Figure 5(b)). Amphibole is a green hornblende forming pœcilitic crystal with inclusions of quartz, plagioclase and zircon. Biotite is a retrograde transformation of hornblende. In the mylonitic portion of the rocks, biotite is recrystallized and associated to the ribbon of quartz. Quartz is anhedral with undulose extinction and usually forms poly crystals ribbon. K-feldspar forms phenocryst bordered by small sizes crystals of quartz and plagioclase. Plagioclase as far as K-feldspar shows undulose extinction. Accessories minerals are zircon, apatite and opaque minerals.

Syenite forms a NE-SW elongated body at the center of the studied area constituted by boulders of various sizes (Figure 6(a)). The rock is granular in texture (Figure 6(b)) and made up of Feldspar; amphibole; pyroxene, biotite, quartz, and accessories minerals (zircon, apatite). Pyroxene is represented by both ortho and clino pyroxene, which confers to the syenite a charnockitic character. They are xenomorphic; orthopyroxene is clearly distinct from then clinopyroxene by a well define (010) sharp cleavage. Amphibole is a green hornblende growing along the cleavage of pyroxene or at their rims (Figure 7). Amphibole crystals always show concentration of opaque minerals along their cleavage. Biotite with brow pleochroism is associated to amphibole. It contains inclusion of zircon and sometime apatite. $\mathrm{K}$ feldspar is characterized by crystals showing flame perthitic albite intergrowth. Plagioclase is partially alternated into sericite. Quartz is interstitial between others minerals and portrays undulose extinction. Accessory minerals are made up of zircon, apatite, titanite and opaque minerals.

Pyroxene and garnet bearing gneiss (PGGn) is located at the border of Cameroon and Chad, and extends from the southern border of the study area till the confluence between Mbere and Vina. In thin section, it shows grano to nematoblastic texture with pyroxene, amphibole, garnet, biotite, plagioclase, quartz, apatite; zircon, opaque minerals. Clinoptroxene is transformed onto amphibole along the cleavage and also appears as relic in amphibole crystals. Amphibole is a green hornblende associated to the biotite and opaque minerals. Biotite is characterized by it brownish color and many inclusions of zircon and/or monazite. Garnet is xenomorphic, associated to feldspar and opaque minerals, and shows crystallization of biotite along its cracks (Figure 8(a)). Plagioclase form crystals often affected by deformation. Some crystals exhibit bent twin lamellas and the others deformational kink-bands. Quartz is characterized by an undulose extinction and also form polycrystalline aggregate surrounding others minerals.

Amphibole, biotite gneiss (ABGn) occupies the SE corner of the study area, cropping out as flagstone in the savanna (Figure 8(b)). The rock is grano-lepidoblastic in texture with biotite; amphibole, feldspar, quartz, zircon, opaque minerals. Amphibole is a green hornblende associated to brown biotite which shows concentration

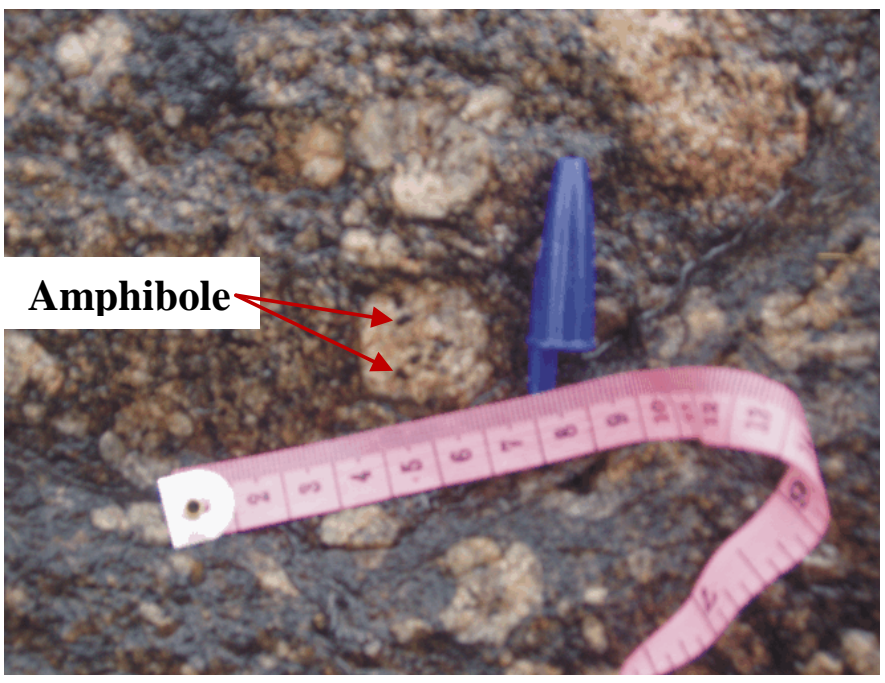

(a)

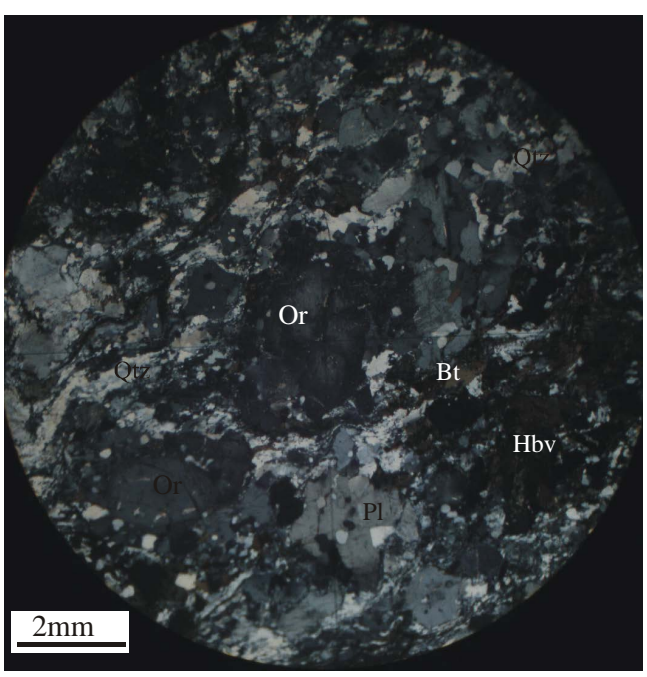

(b)

Figure 5. (a) Phenocrysts of K-feldspar in the granodiorite showing inclusions of amphiboles at Matao (N07 $44^{\prime} 40^{\prime \prime}$; E015 51'36"); (b) Protomylonitic fabric in the granodiorite (cross-polarized light). Or: Kfeldspar, Bt: biotite, Hbv: green hornblende, Qtz: quartz, Pl: plagioclase. 


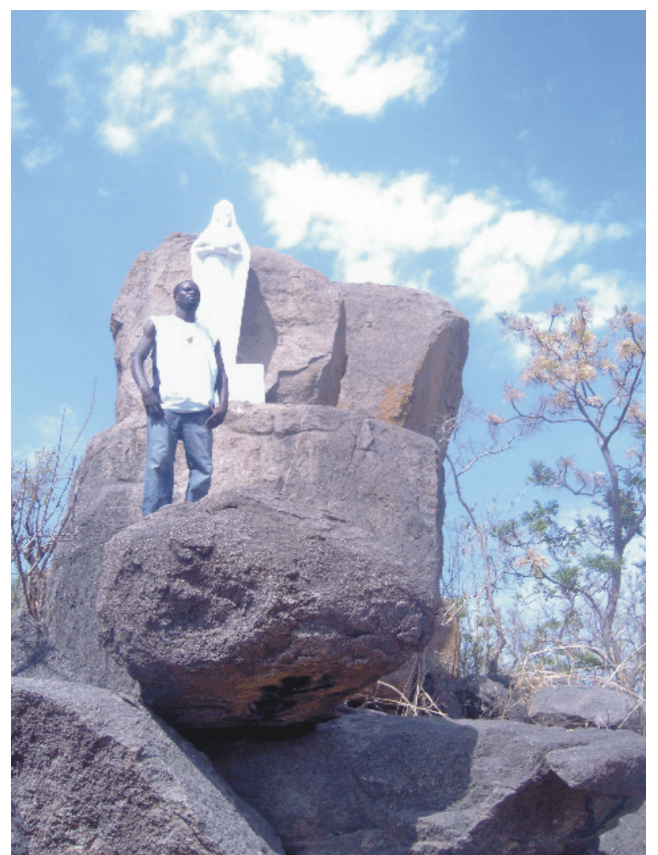

(a)

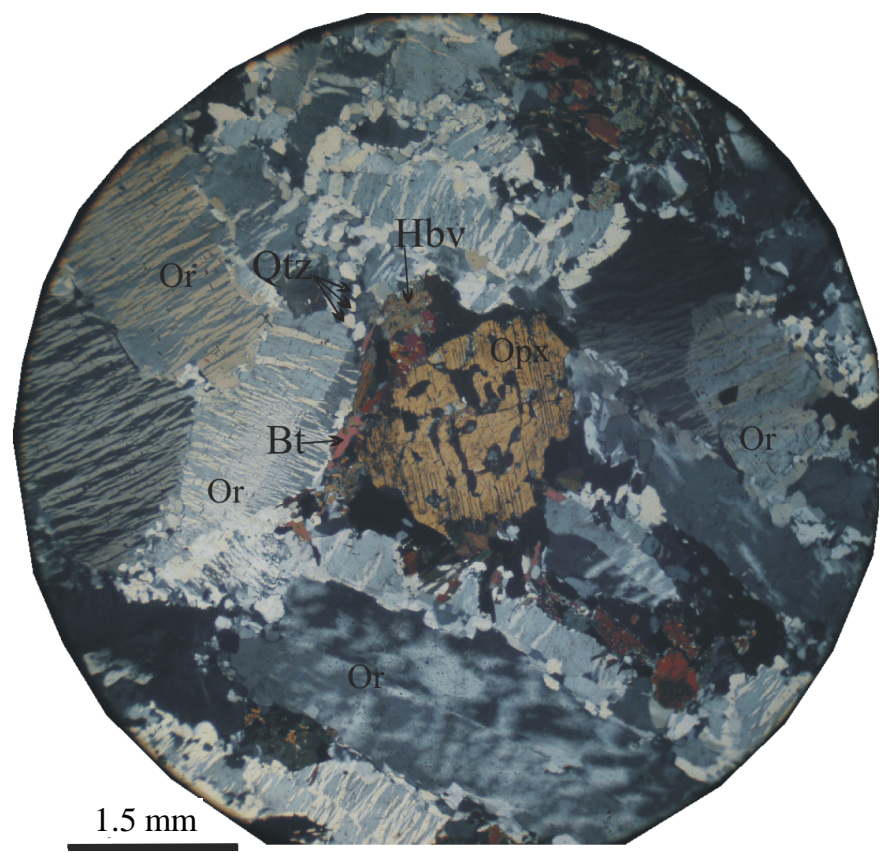

(b)

Figure 6. (a) Out crops of syenite with boulders behind the Chapel at Baïbokoum (N744'10"; E1540'59"); (b) Texture of the syenite (cross-polarized light). Or: Kfeldspar, Bt: biotite, Hbv: green hornblende, Opx: orthopyroxene, Qtz: quartz.

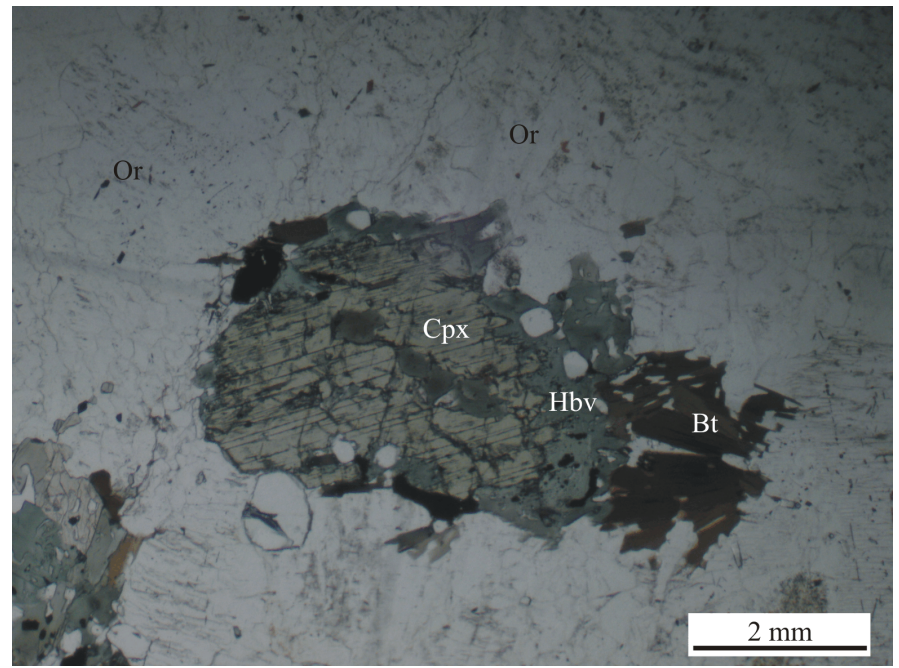

Figure 7. Clinopyroxene rimed by amphibole. Cpx: clinopyroxene, Hbv: green hornblende, Bt: biotite.

of opaque minerals along the cleavage. Biotite is sometime transformed into chlorite and regularly contains inclusion of zircon. Feldspar is represented by plagioclase and microcline with fine plain twinning. Plagioclase is sometime being transformed into sericite and is often pigmented by submicroscopic opaque minerals. Feldspar is associated to quartz and all show undulose extinction.

Banded amphibolite appears as layer of 30 to $35 \mathrm{~cm}$ thick in the gneiss. The banded structure is due to the presence of leucocratic thin layers, product of migmatization parallel to the foliation of the rock.

\section{Geochemistry}

Chemical analyses of the study rocks are represented in the Table 1. The $\mathrm{SiO}_{2}$ vs. $\left(\mathrm{Na}_{2} \mathrm{O}+\mathrm{K}_{2} \mathrm{O}\right)$ diagram [17] is 


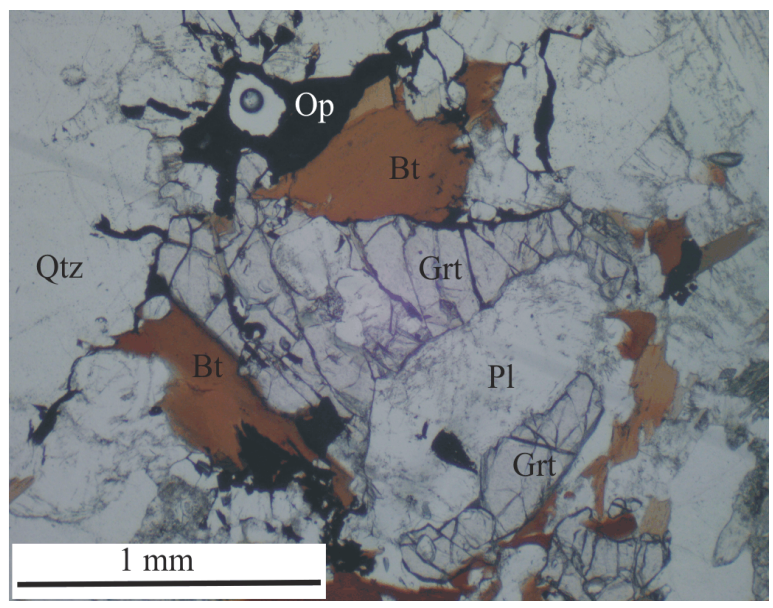

(a)

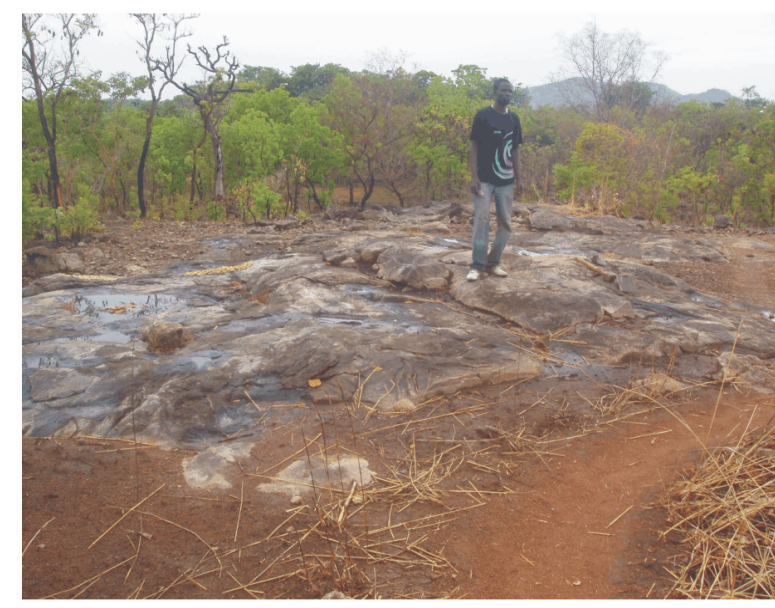

(b)

Figure 8. (a) Association of garnet, biotite, opaque minerals, plagioclas and quartz in the pyroxene and garnet bearing gneiss. Grt: garnet, Bt: biotite, Op: opaque mineral, Qtz: quartz; (b) Amphibole, biotite gneiss croping out as flagstone at Matao (N744'37"; E1550'37").

used for chemical classification of the samples (Figure 9). Granites are ploted in the field of Alkali granite, with one gneiss sample in the field of diorite and two amphibole-biotite granite samples in the fields of granodiorite and syenite respectively. Studied rocks are acid to slightly intermediate in composition $\left(\mathrm{SiO}_{2}>60 \%\right)$. Studied rocks span a narrow compositional range in silica content from $60.5 \mathrm{wt} \%$ to $73.6 \mathrm{wt} \%$. They have high values of alkali oxides, with $\mathrm{K}_{2} \mathrm{O}=1.7 \mathrm{wt} \%-8.0 \mathrm{wt} \%$ and $\mathrm{Na}_{2} \mathrm{O}=2.5 \mathrm{wt} \%-5.4 \mathrm{wt} \%$, and of $\mathrm{Fe}_{2} \mathrm{O}_{3}$ * (total $\mathrm{Fe}$ ) $=1.0 \mathrm{wt} \%$ - $7.0 \mathrm{wt} \%$, but low abundance in $\mathrm{MnO}=0.0 \mathrm{wt} \%-0.1 \mathrm{wt} \%, \mathrm{MgO}=0.2 \mathrm{wt} \%-3.6 \mathrm{wt} \%, \mathrm{CaO}=0.5 \mathrm{wt} \%-4.9$ $\mathrm{wt} \%, \mathrm{P}_{2} \mathrm{O}_{5}=0.0 \mathrm{wt} \%-0.8 \mathrm{wt} \%$. The $\mathrm{TiO}_{2}$ content is moderate $(0.1 \mathrm{wt} \%-1.1 \mathrm{wt} \%) . \mathrm{Al}_{2} \mathrm{O}_{3}$ ranges from 11.3 wt $\%$ to $16.3 \mathrm{wt} \%$.

Plots of major element abundances against $\mathrm{SiO}_{2}$ (Figure 10) do not show a well-defined linear covariation with respect to increasing silica contents. A slight decrease in $\mathrm{TiO}_{2}, \mathrm{MgO}, \mathrm{Fe}_{2} \mathrm{O}_{3}, \mathrm{MnO}$, and a scattered distribution of $\mathrm{Al}_{2} \mathrm{O}_{3}, \mathrm{Na}_{2} \mathrm{O}, \mathrm{CaO}$ and $\mathrm{P}_{2} \mathrm{O}_{5}$ are shown in Figure 10. This could mean that the studied rocks derive from magma of different sources and perhaps of different ages.

In the $\mathrm{K}_{2} \mathrm{O}$ vs $\mathrm{SiO}_{2}$ diagram [18] (Figure 11(a)), the Touboro-Baibokoum rocks portray high-K calc-alkaline (gneiss) to shoshonitic character (amp-Biot granite, Biot Granite, Syenite), with however one banded amphibolite sample in the high calc-alkaline suite and the other in the medium-K calc-alkaline suite. The general highpotassic character of the studied rocks is concordant with their $\mathrm{Al}_{2} \mathrm{O}_{3}$ content higher than 9\% [19] [20] and with their noticeable abundance of K-feldspar (and hence of $\mathrm{K}_{2} \mathrm{O}$ ).

In the TAS diagram [21] offering a classification in alkaline, mid-alkaline and sub-alkaline (calc-alkaline + tholeiitic), studied rocks are in the field of mid-alkaline series (Figure 11(b)). ASI ratios (A/CNK $=\left[\mathrm{Al}_{2} \mathrm{O}_{3} /\right.$ $\left(\mathrm{CaO}+\mathrm{Na}_{2} \mathrm{O}+\mathrm{K}_{2} \mathrm{O}\right.$ ) mole\%]) (Table 1 ) vary from 0.55 to 1.05 revealing their metaluminous to slightly peraluminous character as far as their I-type (Figure 12(a), [23] [24]). This character is confirmed in the diagram of Maniar and Piccoli [25], which employs the Shand's molar parameter, A/NK versus A/CNK (Figure 12(b)). This diagram also clearly separates the metaluminous granitoids, which have A/NK ratios defined as molar $\mathrm{Al}_{2} \mathrm{O}_{3} /\left(\mathrm{NaO}+\mathrm{K}_{2} \mathrm{O}\right)$ greater than 1 , and the peralkaline granitoids $(\mathrm{A} / \mathrm{NK}<1)$. One amphibole biotite granite, one syenite and the biotite granite plot into the peralkaline field. The position of these samples could be explain by their mineralogy; they are rich in alkali mineral (e.g. $\mathrm{K}$ feldspar) which shift down the $\mathrm{Al}_{2} \mathrm{O}_{3} /\left(\mathrm{NaO}+\mathrm{K}_{2} \mathrm{O}\right)$ ratio.

The studied rocks show a wide range of large ion lithophile element (LILE) abundances, Ba (289 - 3540 ppm), Rb (60 - 282 ppm), Sr (259 - 1783 ppm). The high-field-strength elements (HFSE) also vary considerably within the analyzed samples: Y (1 - 66 ppm), Zr (72 - 743 ppm), Ce (46 - 225 ppm), Nb was present in three samples and show a concentration of 31.3, 39.5 and $44.4 \mathrm{ppm}$ respectively. Selected variation diagrams for trace elements ( $\mathrm{Zn}, \mathrm{Cr}, \mathrm{Rb}, \mathrm{Sr}, \mathrm{Zr}$ and $\mathrm{Ba}$ ) as shown in Figure 13 lack any continuous trend. Nevertheless, a poor-defined with gentle decrease for $\mathrm{Rb}, \mathrm{Zr}$ and $\mathrm{Ba}$ with the increasing concentration of $\mathrm{SiO}_{2}$ can be observed. 
Table 1. Geochemical composition of the rocks of the Touboro-Baïbokoum area (b.d.l. = below detection limit).

\begin{tabular}{|c|c|c|c|c|c|c|c|c|c|c|c|c|c|c|}
\hline Sample & TOB & MBE2 & MBE1 & MB2 & MB1 & MA2 & MA1 & G & BAI & KB1 & MBAI & BOK1 & TOUP & LZ1 \\
\hline $\mathrm{SiO}_{2}(\%)$ & 65.617 & 60.509 & 60.924 & 69.969 & 69.896 & 65.623 & 72.848 & 62.309 & 62.386 & 65.16 & 63.68 & 69.23 & 67.13 & 73.58 \\
\hline $\mathrm{TiO}_{2}(\%)$ & 0.478 & 0.828 & 0.745 & 0.383 & 0.308 & 0.994 & 0.213 & 0.833 & 0.825 & 1.11 & 0.928 & 0.792 & 0.406 & 0.19 \\
\hline $\mathrm{Al}_{2} \mathrm{O}_{3}(\%)$ & 15.791 & 16.269 & 16.139 & 15.35 & 15.17 & 14.26 & 14.109 & 14.055 & 15.92 & 12.07 & 11.33 & 11.34 & 13.73 & 12.12 \\
\hline $\mathrm{Fe}_{2} \mathrm{O}_{3}(\%)$ & 3.39 & 6.486 & 6.72 & 2.15 & 3.05 & 6.237 & 1.925 & 4.638 & 3.801 & 6.538 & 4.653 & 4.873 & 2.423 & 1.369 \\
\hline $\mathrm{MnO}(\%)$ & 0.065 & 0.108 & 0.108 & 0.025 & 0.054 & 0.089 & 0.034 & 0.066 & 0.049 & 0.0889 & 0.0664 & 0.0578 & 0.0378 & 0.0143 \\
\hline MgO (\%) & 1.379 & 3.564 & 3.367 & 0.649 & 1.48 & 0.932 & 0.388 & 3.128 & 1.994 & 1.1 & 2.803 & 0.846 & 1.41 & 0.291 \\
\hline $\mathrm{CaO}(\%)$ & 2.699 & 4.602 & 4.868 & 1.567 & 2.999 & 2.605 & 1.323 & 2.923 & 2.193 & 4.701 & 3.818 & 2.601 & 1.904 & 1.32 \\
\hline $\mathrm{Na}_{2} \mathrm{O}(\%)$ & 4.369 & 3.822 & 3.567 & 3.956 & 4.73 & 3.002 & 3.099 & 4.138 & 4.657 & 2.96 & 3.243 & 2.5 & 3.779 & 2.78 \\
\hline $\mathrm{K}_{2} \mathrm{O}(\%)$ & 5.166 & 2.881 & 2.202 & 4.996 & 1.68 & 4.999 & 5.443 & 6.232 & 6.858 & 4.826 & 7.628 & 6.646 & 7.918 & 7.586 \\
\hline $\mathrm{P}_{2} \mathrm{O}_{5}(\%)$ & 0.186 & 0.22 & 0.267 & 0.144 & 0.09 & 0.374 & 0.074 & 0.543 & 0.47 & 0.539 & 0.822 & 0.344 & 0.193 & 0.0766 \\
\hline LOI (\%) & 0.43 & 0.96 & 0.69 & 0.48 & 0.5 & 0.46 & 0.29 & 0.45 & 0.22 & 0.49 & 0.354 & 0.41 & 0.414 & 0.455 \\
\hline Sum (\%) & 100.01 & 100.48 & 99.81 & 99.98 & 100.06 & 99.96 & 99.94 & 99.86 & 99.98 & 99.58 & 99.33 & 99.64 & 99.34 & 99.78 \\
\hline $\mathrm{Na}_{2} \mathrm{O}+\mathrm{K}_{2} \mathrm{O}$ & 9.535 & 6.703 & 5.769 & 8.952 & 6.41 & 8.001 & 8.542 & 10.37 & 11.515 & 7.786 & 10.871 & 9.146 & 11.697 & 10.366 \\
\hline $\mathrm{Na}_{2} \mathrm{O} / \mathrm{K}_{2} \mathrm{O}$ & 0.85 & 1.33 & 1.62 & 0.79 & 2.82 & 0.60 & 0.57 & 0.66 & 0.68 & 0.61 & 0.43 & 0.38 & 0.48 & 0.37 \\
\hline $\mathrm{A} / \mathrm{CNK}$ & 0.89 & 0.92 & 0.94 & 1.04 & 1.01 & 0.95 & 1.05 & 0.74 & 0.83 & 0.65 & 0.55 & 0.71 & 0.75 & 0.80 \\
\hline $\mathrm{A} / \mathrm{NK}$ & 1.24 & 1.73 & 1.96 & 1.29 & 1.58 & 1.38 & 1.28 & 1.04 & 1.06 & 1.20 & 0.83 & 1.00 & 0.93 & 0.95 \\
\hline Mg\# & 0.45 & 0.52 & 0.50 & 0.37 & 0.49 & 0.23 & 0.29 & 0.57 & 0.51 & 0.25 & 0.22 & 0.22 & 0.49 & 0.26 \\
\hline Ва (PPM) & 2796.5 & 1077.7 & 849.3 & 1815.8 & 288.9 & 2026.6 & 1121.8 & 2525.8 & 3190.4 & 1970 & 3540 & 1510 & 3400 & 1270 \\
\hline Сo (PPM) & b.d.l. & 8.5 & 5.6 & b.d.l. & b.d.l. & b.d.l. & b.d.l. & b.d.l. & b.d.l. & & & & & \\
\hline $\mathrm{Cr}(\mathrm{PPM})$ & 5.9 & 101.4 & 65.8 & 0 & 25.9 & 0 & 0 & 74.3 & 17.8 & 248 & 263 & 256 & 294 & 250 \\
\hline Ni (PPM) & 34.6 & 69.9 & 59.5 & 52.5 & 33.4 & 97.5 & 37.5 & 172.5 & 105.8 & & & & & \\
\hline $\mathrm{Rb}(\mathrm{PPM})$ & 122.7 & 73.4 & 60.5 & 218.7 & 125.6 & 158.8 & 142.2 & 255.9 & 281.7 & 138 & 232 & 251 & 213 & 148 \\
\hline $\mathrm{Sr}(\mathrm{PPM})$ & 926.2 & 480.4 & 552.3 & 388.8 & 297 & 289.9 & 258.6 & 898.9 & 1328.8 & 447 & 1424 & 265 & 1743 & 320 \\
\hline V (PPM) & 66.4 & 131.8 & 107.7 & 41 & 49.2 & 68.2 & 20 & 102.1 & 92.4 & & & & & \\
\hline Y (PPM) & 19.3 & 23.2 & 18.3 & 6.7 & 9.5 & 66.3 & 10.2 & 44 & 29.5 & & & & & \\
\hline Zn (PPM) & 34.8 & 73.6 & 65.6 & 22.1 & 43 & 92.3 & 13.7 & 49.9 & 27.9 & 150 & 103 & 112 & 99 & - \\
\hline $\mathrm{Zr}(\mathrm{PPM})$ & 204.2 & 147 & 177.4 & 245.6 & 105.1 & 585.2 & 157.7 & 914 & 665.5 & 743 & 458 & 517 & 272.3 & 158 \\
\hline Ce (PPM) & 110.7 & 70.9 & 89.3 & 176.3 & 46.3 & 225 & 91.1 & 220 & 186.1 & & & & & \\
\hline $\mathrm{Eu}(\mathrm{PPM})$ & 2.2 & 1.4 & 1.8 & 1.3 & 0.9 & 1.6 & 0.9 & 2.2 & 3 & & & & & \\
\hline $\mathrm{La}(\mathrm{PPM})$ & 56.6 & 27.4 & 45.8 & 89 & 28.1 & 82.7 & 37.6 & 81.3 & 77.6 & & & & & \\
\hline $\mathrm{Nb}$ (PPM) & b.d.l. & b.d.l. & b.d.l. & b.d.l. & b.d.l. & 39.5 & b.d.l. & 44.4 & 31.3 & & & & & \\
\hline Nd (PPM) & 29.3 & 20.9 & 28 & 47.2 & 13.2 & 95.9 & 29.7 & 68.8 & 49.5 & & & & & \\
\hline Sm (PPM) & 3.6 & 3.6 & 6.8 & 9 & 4.4 & 13.6 & 5.1 & 7 & 6.3 & & & & & \\
\hline $\mathrm{Yb}(\mathrm{PPM})$ & 1.6 & 2 & 1.4 & 0.5 & 1.1 & 5.5 & 1 & 2.4 & 1.6 & & & & & \\
\hline $\mathrm{K} / \mathrm{Rb}$ & 349.49 & 325.82 & 302.13 & 189.63 & 111.03 & 261.31 & 317.74 & 202.16 & 202.09 & 290.29 & 272.93 & 219.79 & 308.58 & 425.48 \\
\hline $\mathrm{Rb} / \mathrm{Sr}$ & 0.13 & 0.15 & 0.11 & 0.56 & 0.42 & 0.55 & 0.55 & 0.28 & 0.21 & 0.31 & 0.16 & 0.95 & 0.12 & 0.46 \\
\hline
\end{tabular}




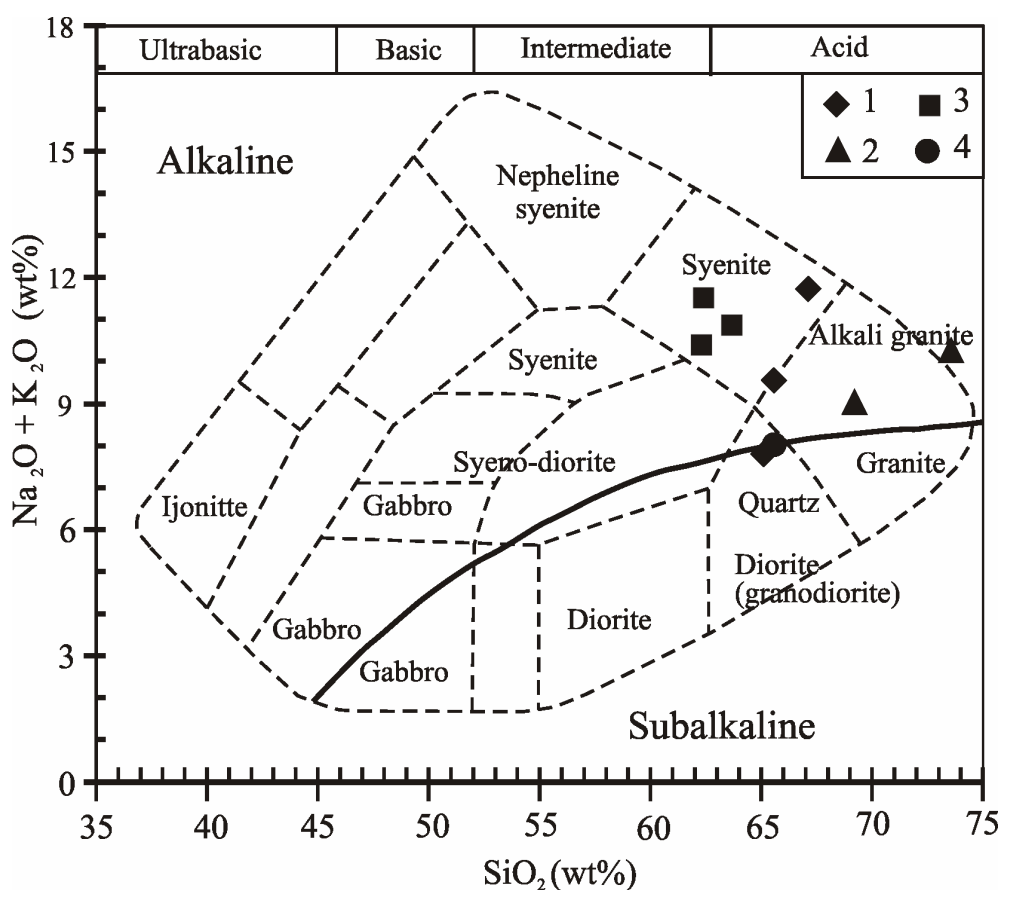

Figure 9. Classification of the studied rocks in the $\mathrm{SiO}_{2}$ vs. $\mathrm{Na}_{2} \mathrm{O}+\mathrm{K}_{2} \mathrm{O}$ diagrams [17]. (1: Amphibole-Biotite Granite; 2: Pyroxene Amphibole Biotite Granite; 3: Syenite; 4: Granodiorite).

\section{Discussion and Conclusion}

The precambrian basement of Touboro-Baïbokoum is made up of rocks wich petrography and chemical characters portray characteristic of high-K to schoshonitic suites [18] with feature of I-type granitoids [23] [26]. The high-K content and calc-alcaline nature of these rocks suggest that the most suitable protholiths could be ancient volcanic rocks [27]. Partial melting of various source rocks, such as amphibolites, tonalitic gneiss, metapelite, and metagreywackes in terms of molar $\mathrm{Al}_{2} \mathrm{O}_{3} /(\mathrm{MgO}+\mathrm{FeOt})-\mathrm{CaO} /(\mathrm{MgO}+\mathrm{FeOt})$, has been discussed by Alther et al. [28]; in the corresponding diagram for the rocks of the Touboro-Baïbokoum area (Figure 14), most of the studied samples derive from the partial melts from metabasaltic to metatonalitic sources. Metabasaltic to metatonalitic sources have been demonstrated for the I-type granite from the Lachan Fold Belt, SE Australia [26]. One sample of pyroxene-amphibole-biotite granite is in the field of the rocks derivate from partial melts from metagrewackes. This distribution could portray the contribution of the crustal material to its source. Such granite of crustal origin and the contribution of crustal material to the source of granitoids have been demonstrated in the Cameroonian portion of the Adamawa-Yade Domain [12] [33]. Many I type granite e.g. Ngondo, Batié and Fomopéa [34]-[36] of west Cameroon show the same characteristics. This suggests the presence of a sedimentary component either in their source, or incorporated by the granitoid magma. It is likely that biotite granite and gneiss shear the same protholite as it has been shown in the Meiganga area [37] that Neoproterozoic leucogranite was formed by melting of the crustal material similar to the inferred protolith of amphibole biotite gneiss. The presence of biotite and amphibole in the pyroxene-amphibole-biotite granite is consistent with the water saturation of the magma. One wonders how Magma of such composition could lead to crystallization of pyroxene. The presence of such an anhydrous mineral in a water saturated environment can be understood only if it is considered as a foreign body. The fact that clinopyroxene is rimed by amphibole portrays the instability of this mineral in the granitic magma. Clinopyroxene is thus a mineral of the basement, probably the pyroxene-garnet gneiss, incorporated into the magma during its emplacement. Xenocrystals of clinopyroxene rimed by amphibole have been reported in the granite to the south of Meiganga in Cameroon [33].

The high-K concentration of the studied rocks is reflected in their high content of biotite and K-feldspar minerals. Intermediate to felsic composition of granitoid is consistent with a derivation from the ancient source of tonalitic to granodioritic composition [38]. Syenite of Baïbokoum shows charnockitic character with presence of both 

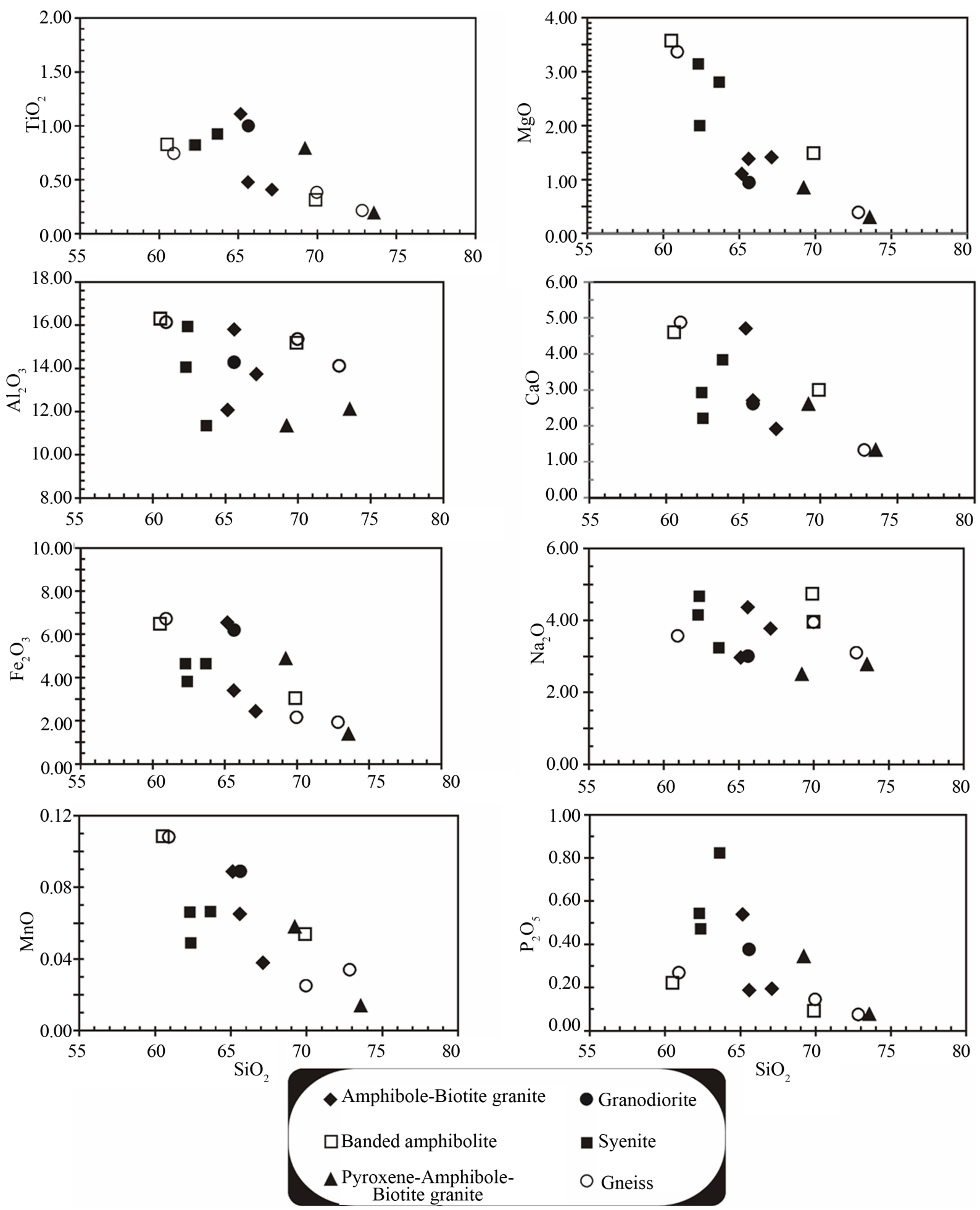

Figure 10. Variation diagrams for some major elements (wt\%) plotted against $\mathrm{SiO}_{2}$ (wt\%) content of Touboro-Baïbokoum rocks.

ortho and clinopyroxene. Due to this, it has been considered as part of the Archeans formation by earlier authors (see [1]). In Meiganga area, pyroxene-amphibole-bearing gneiss shows the geochemical characteristics of archean TTG associations [39] and the REE content allowed considering some samples as derived from Archean 


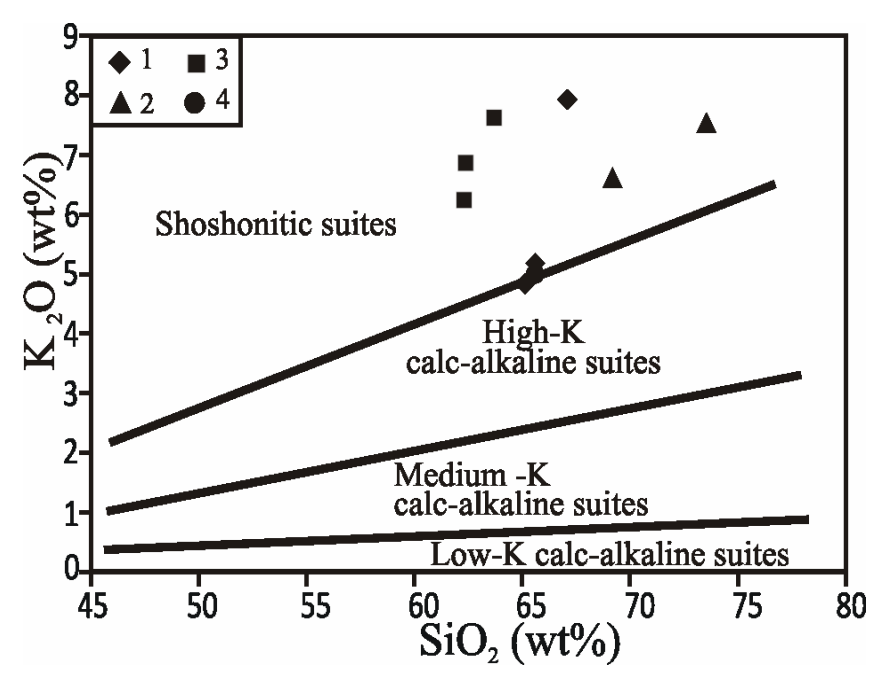

(a)

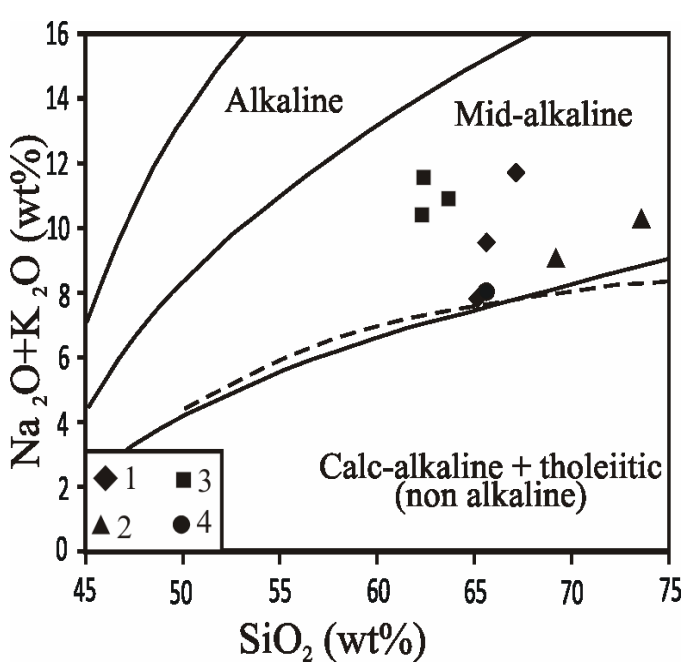

(b)

Figure 11. (a) Classification of Touboro-Baïbokoum rocks in the $\mathrm{K}_{2} \mathrm{O}$ vs. $\mathrm{SiO}_{2}$ diagram with compositional domains of the different calc-alkaline series (after [18]); (b) $\mathrm{Na}_{2} \mathrm{O}+\mathrm{K}_{2} \mathrm{O}$ versus $\mathrm{SiO}_{2}$ (wt\%) diagram after [21] showing the mid-alkaline affinities of the Touboro-Baïbokoum studied rocks. The dashed line shown for comparison is the Miyashiro [22] boundary distinguishing between alkaline and sub-alkaline granitoids. (1: Amphibole-Biotite Granite; 2: Pyroxene-Amphibole-Biotite granite; 3: Syenite; 4: Granodiorite).

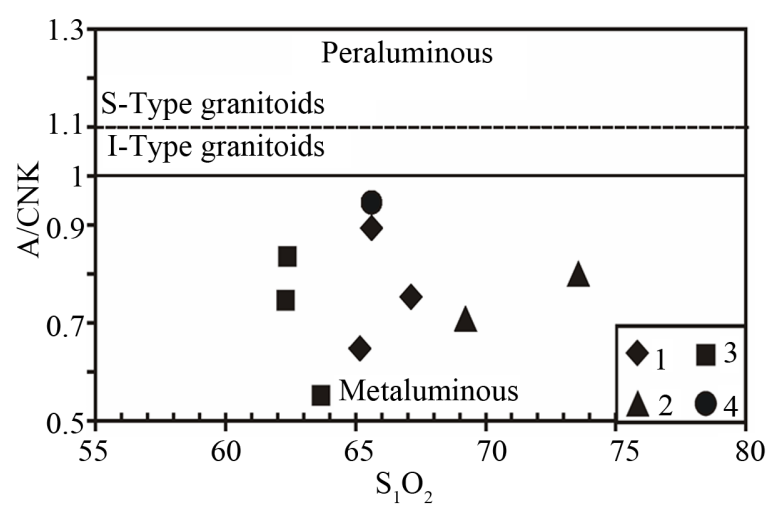

(a)

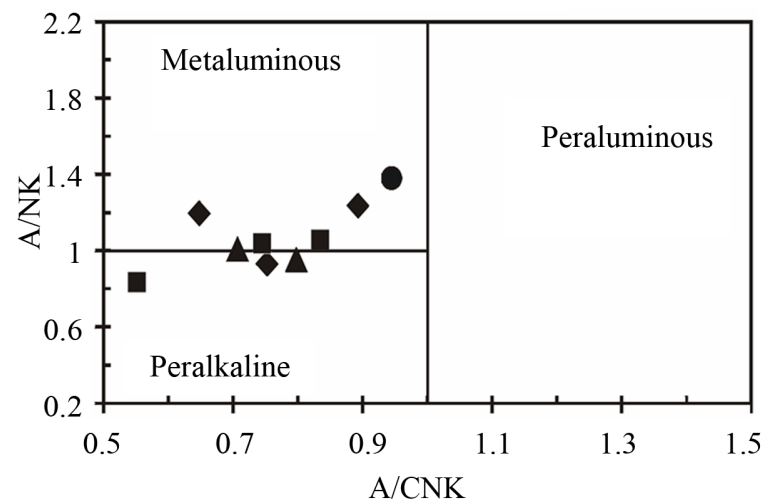

(b)

Figure 12. Metaluminous to peraluminous characters of the Touboro-Baïbokoum rocks. (a) Aluminium saturation index, $\mathrm{A} / \mathrm{CNK}=$ molar $\mathrm{Al}_{2} \mathrm{O}_{3} /\left(\mathrm{CaO}+\mathrm{Na}_{2} \mathrm{O}+\mathrm{K}_{2} \mathrm{O}\right)$ versus $\mathrm{SiO}_{2}(\mathrm{wt} \%)$. The boundary separating the metaluminous and peraluminous domain (continued line) is of Chappell and White [23], while the dashed line dividing the peraluminous domain in weakly and strongly is as summarized by Zen [24]; (b) Shand's molar parameters, A/NK $=\mathrm{Al}_{2} \mathrm{O}_{3} /\left(\mathrm{Na}_{2} \mathrm{O}+\mathrm{K}_{2} \mathrm{O}\right)$ versus $\mathrm{A} / \mathrm{CNK}=\mathrm{Al}_{2} \mathrm{O}_{3} /\left(\mathrm{CaO}+\mathrm{Na}_{2} \mathrm{O}+\mathrm{K}_{2} \mathrm{O}\right)$ in the diagram after [25]. (1: Amphibole-Biotite Granite; 2: Pyroxene-AmphiboleBiotite Granite; 3: Syenite; 4: Granodiorite).

crust. Nevertheless, geochronological and isotopical study are necessary to more unravel the history of the Touboro-Baïbokoun area.

The rocks of the Touboro-Baïbokoum area show petrographic and chemical features as the rocks of westward areas of Meiganga and Ngaoundere. This similitude, in addition to the outcrop feature, strengths the consideration that these areas are parts of the same domain of the Central African Fold belt (CAFB), the Adamawa Yadé Domain (AYD).

\section{Acknowledgements}

Thanks go to anonymous reviewers for their critical reviews of the manuscript. The second author (GAA) is 

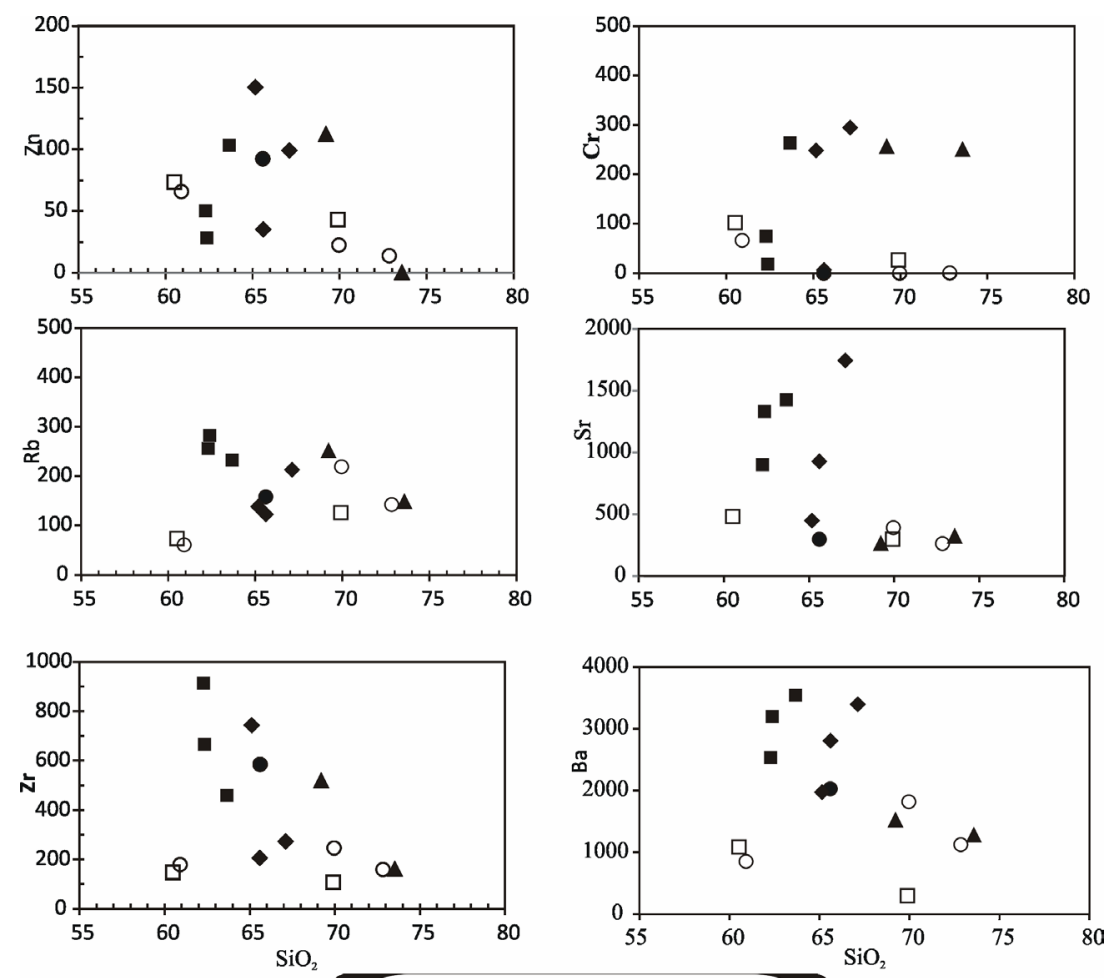

Amphibole-Biotite granite Granodiorite

$\square$ Banded amphibolite

$\Delta$ Pyroxene-AmphiboleBiotite granite

- Syenite

O Gneiss

Figure 13. Variation diagrams of selected trace elements (ppm) versus $\mathrm{SiO}_{2}$ content (wt\%) of Touboro-Baïbokoum rocks.

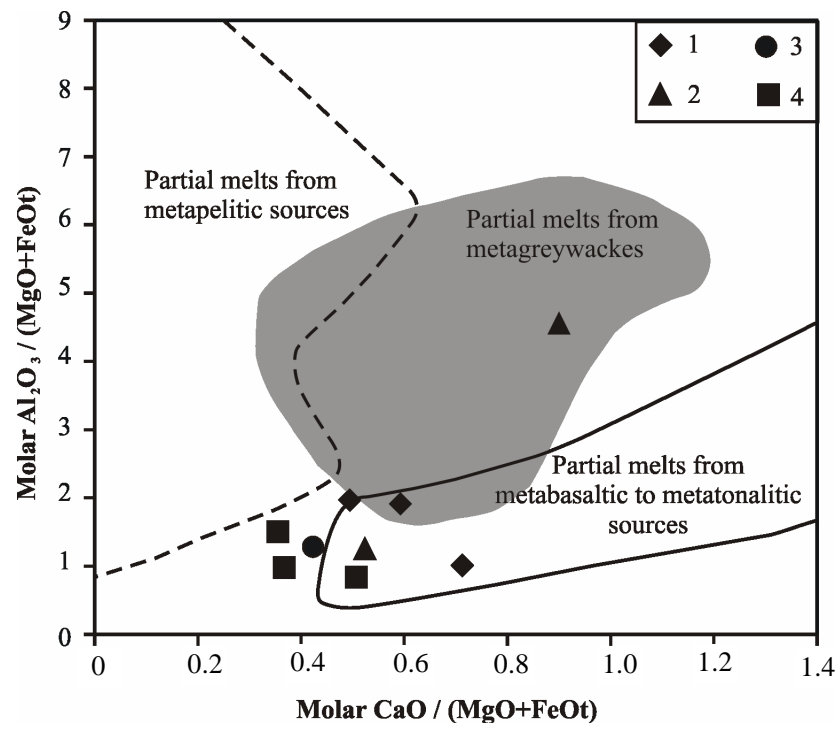

Figure 14. Position of the rocks of Touboro-Baïbokoum area in the molar $\mathrm{Al}_{2} \mathrm{O}_{3} /(\mathrm{MgO}+\mathrm{FeOt})-\mathrm{CaO} /(\mathrm{MgO}+\mathrm{FeOt})$ diagram [28] Fields of partial melts derived from experimental dehydrationmelting of various source rocks: [29]-[32] [38]. (1: AmphiboleBiotite Granite; 2: Pyroxene-Amphibole-Biotite Granite; 3: Syenite; 4: Granodiorite). 
highly indebted to the WFW (Fonds zur Förderung der wissenschaftlichen Forschung) for support of his postdoctoral research at University of Vienna (Austria).

\section{References}

[1] Bessoles, B. and Trompette, M. (1980) Géologie de l’Afrique: La chaîne panafricaine, "zone mobile d’Afrique Central (partie sud) et zone mobile soudanaise”. Mémoire du Bureau de Recherche Géologiques et Minières, 92, 396.

[2] Nzenti, J.P., Barbey, P., Macaudiere, J. and Soba, D. (1988) Origin and Evolution of the High-Grade Yaounde Gneisss (Cameroon). Precambrian Research, 38, 91-109. http://dx.doi.org/10.1016/0301-9268(88)90086-1

[3] Cahen, L., Snelling, N.J., Delhal, J. and Vail, J.R. (1984) The Geochronology and Evolution of Africa. Clarendon Press, Oxford, 512.

[4] Pinna, P., Calvez, J.Y., Abessolo, A., Angel, J.M., Mekoulou-Mekoulou, T., Mananga, G. and Vernhet, Y. (1994) Neoproterozoic Events in the Tcholliré Area: Pan-African Crustal Growth and Geodynamics in Central-Northern Cameroon (Adamawa and North Provinces). Journal of African Earth Sciences, 18, 347-353. http://dx.doi.org/10.1016/0899-5362(94)90074-4

[5] Rolin, P. (1995) La zone de décrochements panafricains des Oubanguides en République Centrafricaine. Comptes Rendu de l'Académie des Sciences de Paris, 320, 63-69.

[6] Toteu, S.F., Van Schmus, R.W., Penaye, J. and Michard, A. (2001) New U-Pb and Sm-Nd Data from North-Central Cameroon and Its Bearing on the Pre-Pan-African History of Central Africa. Precambrian Research, 108, 45-73. http://dx.doi.org/10.1016/S0301-9268(00)00149-2

[7] Toteu, S.F., Penaye, J. and Poudjom Djomani, Y. (2004) Geodynamic Evolution of the Pan-African Belt in Central Africa with Special Reference to Cameroon. Canadian Journal of Earth Sciences, 41, 73-85. http://dx.doi.org/10.1139/e03-079

[8] Ganwa, A.A., Doumnang Mbaigane, J.C. and Lagmet, C. (2009) Pétrographie et données structurales sur les dômes rhyolitiques du sud du Lac Tchad (Dandi-Hadjer El Hamis): Relation avec la Ligne du Cameroun. Rev. CAMES-Série A, Vol. 08. http://lithosphere.univie.ac.at/fileadmin/user_upload/dep_lithosphaere/ganwa-rev-cames.pdf

[9] Penaye, J., Kröner, A., Toteu, S.F., Van Schmus, W.R. and Doumnang, J.C. (2006) Evolution of the Mayo Kebbi Region as Revealed by Zircon Dating: An Early (ca. 740 Ma) Pan-African Magmatic Arc in Southwestern Chad. Journal of African Earth Sciences, 44, 530-542. http://dx.doi.org/10.1016/j.jafrearsci.2005.11.018

[10] Ngako, V., Jegouzo, P. and Nzenti, J.P. (1991) Le Cisaillement Centre-Camerounais. Rôle structural et géodynamique dans l'orogenèse panafricaine. Comptes Rendus de l'Académie des Sciences Paris, 315, 457-463.

[11] Lasserre, M. (1961) Etude géologique de la partie orientale de l'Adamaoua (Cameroun Central) et les principales sources minéralisées de l’Adamaoua. Bulletin de la Direction des Mines et Géologie du Cameroun, 4, 130.

[12] Tchameni, R., Pouclet, A., Penaye, J., Ganwa, A.A. and Toteu, S.F. (2006) Petrography and Geochemistry of the Ngaoundéré Pan-African Granitoids in Central North Cameroon: Implications for Their Sources and Geological Setting. Journal of African Earth Sciences, 44, 511-529. http://dx.doi.org/10.1016/j.jafrearsci.2005.11.017

[13] Ganwa, A.A., Frisch, W., Siebe, W. and Shang, C.K. (2011) Geochemistry of Magmatic Rocks and Time Constraints on Deformational Phases and Shear Zone Slip in the Méiganga Area, Central Cameroon. International Geology Review, 53, 759-784. http://dx.doi.org/10.1080/00206810903211161

[14] Kusnir, I. (1995) Géologie, Ressources minérales et ressources en eau du Tchad. Trav. Doc. SC. Tchad, connait. Tchad, 1, CNAR., $2^{\text {ème }}$ Edition, Actualiséé et Augm.

[15] Gerard, G. (1963) Notice explicative sur la feuille de Bossangoa-Est. Rapport B.R.G.M., Brazzaville, 61.

[16] Toteu, S.F., Michard, A., Bertrand, J.M. and Rocci, G. (1987) U/Pb Dating of Precambrian Rocks from Northern Cameroon, Orogenic Evolution and Chronology of the Pan-African Belt of Central Africa. Precambrian Research, 37, 71-87. http://dx.doi.org/10.1016/0301-9268(87)90040-4

[17] Le Bas, M.J., Le Maitre, R.W., Streckeisen, A. and Zanettin, B. (1986) A Chemical Classification of Volcanic Rocks Based on the Total-Alkali-Silica Diagram. Journal of Petrology, 27, 745-750. http://dx.doi.org/10.1093/petrology/27.3.745

[18] Pecerillo, A. and Taylor, S.R. (1976) Geochemistry of Eocene Calc-Alkaline Volcanic Rocks from the Kastamonu Area, Northern Turkey. Contributions to Mineralogy and Petrology, 58, 63-81. http://dx.doi.org/10.1007/BF00384745

[19] Morrison, G.W. (1980) Characteristics and Tectonic Setting of the Shoshonite Rock Association. Lithos, 13, 97-108. http://dx.doi.org/10.1016/0024-4937(80)90067-5

[20] Müller, D., Rock, N.M.S. and Groves, D.I. (1992) Geochemical Discrimination between Shoshonitic and Potassic Volcanic Rocks in Different Tectonic Settings: A Pilot Study. Mineralogy and Petrology, 46, 259-289. http://dx.doi.org/10.1007/BF01173568 
[21] Middlemost, E.A.K. (1997) Magmas, Rocks, and Planetary Development. Longman, Harlow, 299.

[22] Miyashiro, A. (1978) Nature of Alkalic Volcanic Rock Series. Contributions to Mineralogy and Petrology, 66, 91-104. http://dx.doi.org/10.1007/BF00376089

[23] Chappell, B.W. and White, A.J.R. (1974) Two Contrasting Granite Types. Pacific Geology, 8, 173-174.

[24] Zen, E. (1986) Aluminum Enrichment in Silicate Melts by Fractional Crystallization: Some Mineralogic and Petrographic Constraints. Journal of Petrology, 27, 1095-1117. http://dx.doi.org/10.1093/petrology/27.5.1095

[25] Maniar, P.D. and Piccoli, P.M. (1989) Tectonic Discrimination of Granitoids. The Geological Society of America, 101, 635-643. http://dx.doi.org/10.1130/0016-7606(1989)101<0635:TDOG>2.3.CO;2

[26] Chappell, B.W. and White, A.J.R. (1992) I- and S-Type Granites in the Lachlan Fold Belt. Transactions of the Royal Society of Edinburgh: Earth Sciences, 83, 1-26. http://dx.doi.org/10.1017/S0263593300007720

[27] Roberts, M.P. and Clemens, J.D. (1993) Origin of High-Potassium Calc-Alkaline, I-Type Granitoids. The Geological Society of America, 21, 825-828. http://dx.doi.org/10.1130/0091-7613(1993)021<0825:OOHPTA>2.3.CO;2

[28] Altherr, R., Holl, A., Hegner, E., Langer, C. and Kreuzer, H. (2000) High-Potassium, Clac-Alkaline I-Type Plutonism in the European Variscides: Northern Vosges (France and Northern Schwarzwald (Germany). Lithos, 50, 51-73. http://dx.doi.org/10.1016/S0024-4937(99)00052-3

[29] Wolf, M.B. and Wyllie, J.P. (1994) Dehydration Melting of Amphibolite at 10 Kbar: The Effects of Temperature and Time. Contribution to Mineralogy and Petrology, 115, 369-383.

[30] Gardien, V., Thompson, A.B., Grujic, D. and Ulmer, P. (1995) Experimental Melting of Biotite + Plagioclase + Quartz \pm Muscovite Assemblage and Implications for Crustal Melting. Journal of Geophysical Research, 100, 15581-15591. http://dx.doi.org/10.1029/95JB00916

[31] Douce, A.E.P. and Beard, J.S. (1995)Dehydration-Melting of Biotite Gneiss and Quartz Amphibolite from 3 to 15 Kbar. Journal of Petrology, 36, 707-738. http://dx.doi.org/10.1093/petrology/36.3.707

[32] Douce, A.E.P. and Beard, J.S. (1996) Effects of $\mathrm{P}, \mathrm{f}\left(\mathrm{O}_{2}\right)$ and $\mathrm{Mg} / \mathrm{Fe}$ Ratio on Dehydration Melting of Model Metagreywackes. Journal of Petrology, 37, 999-1024. http://dx.doi.org/10.1093/petrology/37.5.999

[33] Ganwa, A.A. (2005) Les granitoïdes de Méiganga: Etude pétrographique, géochimique, structurale et géochronologique. Leur place dans la chaîne panafricaine. Thèse d’État ès sciences naturelles, Université de Yaoundé I, Yaoundé, 162.

[34] Kwekam, M. (1993) Le massif plutonique calco-alcalin panafricain de Fomopéa (Ouest Cameroun): Cadre Structural-Pétrochimie-Géochimie-Interprétations Géodynamiques. Thèse de Doctorat, Université de Yaoundé I, Yaoundé, 154.

[35] Tagne-Kamga, G. (2003) Petrogenesis of the Neoproterozoic Ngondo Plutonic Complex (Cameroon, West Central Africa): A Case of Late-Collisional Ferro-Potassic Magmatism. Journal of African Earth Sciences, 36, 149-171. http://dx.doi.org/10.1016/S0899-5362(03)00043-5

[36] Talla, V. (1995) Le Massif granitic panafricain de Batié (Ouest-Cameroun): Pétrologie-Pétrostructurale-Géochimie. Thèse de Doctorat, Université de Yaoundé I, Yaoundé, 144.

[37] Ganwa, A.A., Siebel, W., Kongnyuy, S., Seguem, C.N. and Ekodeck, G.E. (2011) New Constraints from Pb-Evaporation Zircon Ages of the Méiganga Amphibole-Biotite Gneiss, Central Cameroon, on Proterozoic Crustal Evolution. International Journal of Geosciences, 2, 138-147.

[38] Singh, J. and Johannes, W. (1996) Dehydration Melting of Tonalites. Part I. Beginning of Melting. Contribution to Mineralogy and Petrology, 125, 16-25. http://dx.doi.org/10.1007/s004100050203

[39] Ganwa, A.A., Frisch, W., Siebel, W., Ekodeck, G.E., Shang, C.K. and Ngako, V. (2008) Archean Inheritances in the Pyroxene-Amphibole-Bearing Gneiss of the Méiganga Area (Central North Cameroon): Geochemical and 207 Pb/206 $\mathrm{Pb}$ Age Imprints. Comptes Rendus Geoscience, 340, 211-222. http://dx.doi.org/10.1016/j.crte.2007.12.009 